\title{
AIKUISKOULUTTAJAT ROOLIAAN ETSIMÄSSÄ
}

A ikuiskasvatuksen merkitys on nopeasti lisääntymässä. Koulutuksen yhtä hyvin kuin tieteen, kulttuurin, viestinnän, liikunnan ja muiden sivistyspalvelujen tarve kasvaa seuraavina vuosikymmeninä. Kasvun syitä ja seurauksia on tarkasteltu monipuolisesti esimerkiksi useissa opetusministeriön suunnittelusihteeristön julkaisuissa.

Tulevaisuuden pohtijoiden mielestä sivistyksellä on merkitystä sekä itseisarvona että moniin yhteiskunnan tarpeisiin vastaajana. Itseisarvoinen opiskelu korostuu usein sitä enemmän, mitä iäkkäämmästä opiskelijasta on kyse. Tämä tulee hyvin esille tässä lehdessä tarkasteltaessa ikääntyvien koulutuspalveluja ja -tarpeita.

Tulevaisuudessa laaja-alaisesta sivistyksestä tulee todennäköisesti hallitseva päämäärä ja koulutuksen välineellinen merkitys pienenee. Talouskasvu ja täystyöllisyys eivät voi olla tärkeimpiä koulutuksen tavoitteita, vaan muiden elämän alueiden on korostuttava.

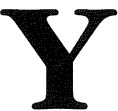
ksi keskeisistä koulutuspoliittisista pullonkauloista on se, että koulutusjärjestelmämme tuottaa korkeasti koulutettuja henkilöitä aloille, joilla on jo valtava työttömyys ja sijoittuminen koulutusta vastaaviin tehtäviin on lähes mahdotonta. Onkin tärkeää, että sekä nuorten että aikuisten koulutus tuottaisi entistä enemmän yleisiä valmiuksia, jotka ovat tärkeitä sekä työelämässä että työelämän ulkopuolelle jääville. Aikuiskoulutuksen tulisi osaltaan turvata työelämästä syrjään jääneiden ammattipätevyyden säilyminen ja toisaalta antaa heille valmiuksia erilaisiin kansalaistoimintoihin, jotka tuovat mielekkyyttä elämään.
Tulevaisuudentutkijat Mika Mannermaa ja Keijo Mäkelä ovat osuvasti todenneet Tulevaisuusbarometri 1993 -raportissaan, että ihmisenä olemisen pätevyysvaatimukset kasvavat. Heidän keräämiensä asiantuntija-arvioiden perusteella tulevaisuudessa korostuvat ammattiin liittyvä osaaminen ja jatkuva oppimiskyky, kommunikaatiovalmiudet, muutoksen sietokyky ja tietointensiivinen osaaminen.

$\mathbf{P}$ aljon pohdittavaa aikuiskouluttajille tarjoaa Niiniluoto, kun hän tarkastelee sivistys-Suomen arvoja. Hän toteaa Lehtisalon Sivistys 2017 -teoksessa mm. että Suomen tulee olla vapaiden ja aktiivisten kansalaisten muodostama demokraattinen oikeusvaltio, jossa kansalaisilla on itsekunnioitusta ja mahdollisuuksia vaikuttaa omaan tulevaisuuteensa. Sen on oltava perinteitä kunnioittava, mutta samalla erilaisuutta suvaitseva kulttuurivaltio, jossa aineellinen ja henkinen toimeliaisuus kukoistavat ja kansainvälinen kanssakäyminen on vilkasta. Sen on oltava luonnon kesto- ja uusiutumiskykyä säästävä ekovaltio, jossa luonnonympäristön arvoja kunnioitetaan ja säilytetään tuleville sukupolville. Sen on oltava korkeatasoiseen tutkimukseen ja koulutukseen perustuva hyvinvointiyhteiskunta, jossa kansalaisten ylenmääräinen holhous on korvattu itsenäisyyttä takaavilla perusoikeuksilla ja positiivisia vapauksia ja toimintamahdollisuuksia antavilla palveluksilla.

Edellä olevat hienot arvot voisivat olla minkä tahansa koulutusorganisaation tavoitepohdintojen lähtökohtina. Erityisen tarpeelliseksi ja toisaalta haastavaksi arvojen tarkastelun tekee yhteiskunnan nykyinen taloudellinen tilanne. Todellisuutta on jo se, että materialistinen an- 
saintapyrkimys hallitsee ihmisten toimintoja.

$\mathbf{V}$ aikka koulutus- ja muiden sivistyspalvelujen tarve kasvaa, julkisen sektorin osuus niiden tuottajana tulee vähenemään. Melko suuri yksimielisyys näyttää olevan siitä, että sivistyspalveluita tarjoavat organisaatiot joutuvat toimimaan entistä pienemmän julkisen tuen varassa. Ne joutuvat rahoittamaan toiminnastaan entistä suuremman osan oman varainhankintansa avulla ja näin monipuolistamaan taloudellista pohjaansa. Taloudellisen tilanteen tekee vielä mielenkiintoisemmaksi se, että myös palvelujen käyttäjien varallisuus on laskenut työttömyyden ja verotuksen takia.

Taloudellisen tilanteen olennainen heikkeneminen johtaa helposti siihen, että pyritään tarjoamaan sellaisia palveluja, jotka varmasti menevät kaupaksi ja joihin löydetään maksukykyisiä asiakkaita. Huippuosaamisen ja tietointensiivisyyden korostajien joukossa tarvittaisiin myös koulutusorganisaatioita, jotka huolehtivat vähäosaisista, pohtisivat eettisiä ja esteettisiä arvoja sekä ekologisia kysymyksiä. Näin voitaisiin jossain määrin ehkäistä kansalaisten jakautumista edelleen A- ja B-luokkiin.

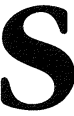
ivistyspalveluihin kohdistuvien kasvavien vaatimusten, päätäntävallan hajauttamisen ja pienempien resurssien seurauksena aikuiskoulutusta antavien organisaatioiden johtajuuden merkitys kasvaa. Vahvoja johtajia tarvitaan entistä enemmän tiennäyttäjiksi, visioiden, unelmien ja tavoitteiden asettajiksi. Koulutusorganisaatiot joutuvat miettimään, mitä arvoja ne ovat toteuttamassa ja mikä niiden todellinen perustehtävä on. Pelkästään yhteiskunnan ja yksilöiden muuttuviin tarpeisiin reagoiminen ei riitä, vaan aikuiskoulutusorganisaatioiden tulee olla myös tiennäyttäjinä tulevaisuuden muodostumisessa.

Onkin välttämätöntä lisätä yrittäjyyttä ja joustavuutta kaikissa koulutusorganisaatioissa. Näin voidaan vapauttaa entistä enemmän aikuiskoulutusorganisaatioissa piilevää luovuutta ja energiaa sekä antaa henkilökunnalle entistä suuremmat mahdollisuudet vaikuttaa toimintaansa. Tällöin vaarana on kuitenkin markkinavetoiset, kansainvälistä kilpailukykyä ja taloudellisuutta korostavat yksiköt, jotka kilpailevat rajusti kes- kenään maksukykyisten asiakkaiden suosiosta.

Suunnannäyttäjän roolin ohella tärkeä vaatimus johtajalle on sekä oman että henkilökuntansa ammattitaidon kehittäminen. Jotta uusiin haasteisiin pystyttäisiin vastaamaan entistä pienemmin resurssein, on koulutusorganisaatioiden huolehdittava omasta osaamisestaan. Niiden tulisi olla mallina muille työyhteisöille systemaattisesta, tavoitteellisesta oman henkilöstönsä henkisestä kasvusta, joka palvelee sekä työntekijöitä itseään että organisaation toimintaa.

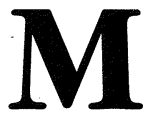

uutospaineiden ja työn vaativuuden lisääntyessä kaikissa koulutusta antavissa organisaatioissa tulee entistä tärkeämmäksi huolehtia henkilökunnan työkykyisyydestä. Henkilöstön tulisi toimia tiiviissä yhteistyössä silloin, kun se on tarkoituksenmukaista. Yhteistoiminnallisuus on merkittävää erityisesti opetusalalla, jossa on vankka yksin toimimisen ja nykyään jopa keskinäisen kilpailun perinne.

Myös oppilaitosten tulisi pyrkiä keskinäiseen yhteistyöhön. Niiden keskinäisen kilpailun sijaan olisi mielekkäämpää kehittää yhteistyöverkostoja. Yhdistämällä eri koulutusorganisaatioiden vahvoja puolia voitaisiin luoda koulutuspalveluja, jotka olisivat entistä monipuolisempia ja korkeatasoisempia. Koulutusohjelmia tulisi siirtää myös entistä joustavammin paikasta toiseen, jotta samoja asioita ei tarvitsisi suunnitella alusta lähtien joka paikassa erikseen.

\section{Kauko Hämäläinen}

